\title{
A SEA LEVEL STRATOSPHERIC OZONE INTRUSION EVENT INDUCED WITHIN A THUNDERSTORM GUST FRONT
}

\author{
Joel DREesSen
}

\author{
Nocturnal thunderstorms coupled with a stratospheric intrusion augmented \\ downward stratospheric ozone transport to impact sea level monitors on the \\ U.S. East Coast on 16 April 2018.
}

AfFILIATION: DreEsSEN-Air Monitoring Program, Maryland Department of the Environment, Baltimore, Maryland CORRESPONDING AUTHOR: Joel Dreessen, joel.dreessen@maryland.gov

The abstract for this article can be found in this issue, following the table of contents.

DOI:10.II75/BAMS-D-18-0113.I

In final form 12 February 2019

C2019 American Meteorological Society

For information regarding reuse of this content and general copyright information, consult the AMS Copyright Policy. the band climbed above 70 ppbv, a level considered "Unhealthy for Sensitive Groups" (USG; color code orange) on the Environmental Protection Agency (EPA) Air Quality Index (AQI) if sustained for the regulatory 8-h average (EPA 2015). However, these ozone levels occurred during nocturnal hours and within significant thunderstorm activity typically associated with cleaner conditions. Furthermore, in contradiction to typical ozone formation within the lower troposphere, these enhanced concentrations of ozone were associated with the passage of a thunderstorm gust front.

Ozone is a naturally occurring molecule with concentrations on the order of $10 \mathrm{ppm}$ in the stratosphere. Concentrations within the troposphere are much lower and highly variable as a secondary photochemical, with concentrations in clean air generally $10-40 \mathrm{ppbv}$ (Seinfeld and Pandis 1998). Generally, the stability between the troposphere and stratosphere allows little air exchange between the two layers. Exceptions occur during stratospheric mixing events, or tropopause folds, often collectively referred to as stratospheric intrusions (SIs). During these events, air from the stratosphere containing large ozone concentrations 




Fig. I. (a) Filled contours of the highest hourly average ozone between 0500 and I 200 UTC (0100-0800 EDT) I6 Apr 2018. Actual concentrations are shown as bold numbers, with monitor locations as black dots. Specific sites called out in the text are annotated. Contours of maximum values were interpolated using a spline method. The Chesapeake Bay is at sea level. (b) Minute-averaged ozone concentrations from the MDE ozone network from 0400 to 2200 UTC (0000-1800 EDT). The ozone time series shows ozone was highest in predawn hours, then decreased during the midmorning and remained low the rest of the day. 
and low anthropogenic pollutants protrudes downward into the troposphere. These SIs are typically associated with and located on the cold side of intense jet streams and are characterized often as elongated horizontal filaments of enhanced ozone (Appenzeller et al. 1996). Enhanced ozone during these events is typically restricted to the upper portions of the troposphere (e.g., Kuang et al. 2012; Sullivan et al. 2015; Ott et al. 2016). On occasion high-elevation (mountaintop) surface monitors will sample stratospheric ozone (Lin et al. 2012; Langford et al. 2015). There are also cases of indirect transport of SI ozone to the surface over time (Davies and Schuepbach 1994), and to low elevations via mixing (Langford et al. 2015). Dempsey (2014) found evidence that suggested a direct influence of stratospheric ozone behind cold fronts in southern Ontario when ozone increased $10-20$ ppbv for about an hour when the front passed. However, there are no known documented cases of direct transport of an SI to sea level along the U.S. East Coast, augmented by a thunderstorm, or resulting in surface ozone of the magnitude observed in this event. The 16 April 2018 event documented here had stratospheric ozone transported to sea level due to a coupling of the SI with deep convection. This may be the first event of its type and magnitude documented.

THE NOCTURNAL OZONE EVENT. Surface ozone concentrations increased in magnitude progressively from southwest to northeast in a broad streak from roughly Richmond, Virginia, to Philadelphia, Pennsylvania, from 0500 to 1200 UTC 16 April 2018, with peak hourly average concentrations highest in the state of Maryland (Fig. 1a) during that time. A 9-ppbv increase in hourly average surface ozone was noted as early as 0500 UTC [0100 local daylight time (LDT)] in Virginia's Prince Edward
County, southwest of Richmond, Virginia (Table 1). Concentrations continued to climb there and spread into Richmond, and also atop the Blue Ridge Mountains at Shenandoah National Park (SNP) in west-central Virginia. The high elevation of the SNP site (approximately 1,070 m MSL) caused it to be spatially prominent among other 1 -h maximum values (Fig. 1a). Hourly average concentrations at SNP jumped 18 ppbv in a single hour. In Richmond, concentrations jumped as much as $32 \mathrm{ppbv}$ in an hour but $44 \mathrm{ppbv}$ in total through 0700 UTC. Increasing ozone reached southern Maryland by 0700 UTC (Fig. 1b) and eventually produced a maximum hourly ozone concentration of $74 \mathrm{ppbv}$ in northeastern Maryland after hourly average increases of nearly 50 ppbv. Nocturnal ozone concentrations increased as far north as the southern suburbs of Philadelphia in New Jersey and Delaware but lost northern progression by 1200 UTC. Enhanced ozone concentrations generally persisted several hours before being swept out by a cold front approaching from the west, apparent at most Maryland ozone monitors as a drop in concentrations from 1100 to 1700 UTC (Fig. 1b).

The dramatic hourly average increases in surface ozone concentrations actually took place within a matter of minutes. The Virginia Department of Environmental Quality Hanover ozone monitor in Richmond recorded a 13-ppbv increase in $5 \mathrm{~min}$ and a 27-ppbv increase over 15 min during the hour of peak increase (Table 1). Observed increases within the Maryland Department of the Environment (MDE) ozone network were even more dramatic (Fig. 1b). Minute-averaged ozone concentrations at Millington, Maryland, increased 42 ppbv in just 3 min, increasing a total of $52 \mathrm{ppbv}$ over $10 \mathrm{~min}$. These sudden increases in ozone progressed from southwest to northeast from Virginia into Maryland and were coincident

\begin{tabular}{|c|c|c|c|c|}
\hline Name (AQS ID) & $\begin{array}{l}\text { Minimum } \\
\text { (ppbv) }\end{array}$ & $\begin{array}{l}\text { Maximum } \\
\text { (ppbv) }\end{array}$ & $\begin{array}{c}\operatorname{Max} \mathrm{I}-\mathrm{h} \Delta \mathrm{O}_{3} \\
\quad(\mathrm{ppbv})\end{array}$ & $\begin{array}{l}\text { Hour of } \max \Delta O \\
\text { (UTC) }\end{array}$ \\
\hline Prince Edward County (5II47999I) & 39 & 54 & 9 & $0500-0600$ \\
\hline SNP (5III30003) & 34 & 52 & 18 & $0600-0700$ \\
\hline Richmond (5I0850003) & 21 & 65 & 32 & $0600-0700$ \\
\hline S. Maryland (240I700I0) & 19 & 63 & 35 & $0700-0800$ \\
\hline Millington (240290002) & 25 & 74 & 44 & $0900-1000$ \\
\hline
\end{tabular}


with the progression of thunderstorm activity. As a result of these sudden ozone increases, a large area of the mid-Atlantic coast was exposed to ozone near or above 70 ppbv (Fig. 1a).

\section{HISTORICAL AVERAGES OF MARYLAND SURFACE OZONE FOR THE MONTH OF}

APRIL. The climatological peak for Maryland surface ozone occurs in July when sun angle, temperature, and weather conditions are most supportive of photochemical production. Warm season shoulder months such as April can experience periods of hourly ozone in excess of $70 \mathrm{ppbv}$ due to special circumstances such as early season agricultural burning and vegetation blooming during warm periods. However, early afternoon (1600-1900 UTC; 1200-1500 EDT) hourly ozone averages only $47 \mathrm{ppbv}$ for all April days and monitors in Maryland from 2013 to 2017. The years 2013-17 better represent the contemporary cleaner atmosphere of the mid-Atlantic [e.g., that mentioned in Dreessen et al. (2016)] than a longer record. Morning (0800-1200 UTC; 0400-0800 EDT) concentrations averaged only $30 \mathrm{ppbv}$ over the same 5 -yr period, and the 99th percentile of all April morning hourly values in Maryland was 52 ppbv. On 16 April 2018 the Millington, Maryland, monitor observed an hourly average of $74 \mathrm{ppbv}$ at $1000 \mathrm{UTC}$, which was the highest hourly average morning observation of all time for all months for that site since records began in 1989 (31,695 hourly observations).

A period of enhanced photochemical production of surface ozone occurred 13-14 April in Maryland due to agricultural burning. A large number of fires detected by Visible Infrared Imaging Radiometer Suite (VIIRS) and Geostationary Operational Environmental Satellite (GOES) satellites burned from 10 to 14 April 2018 across the southeastern quarter of the continental United States (CONUS), which caused a large area of diffuse smoke suspected of driving moderate ozone air quality ( 8 -h average concentrations of $55-70 \mathrm{ppbv}$ ) during afternoon hours across the same region. Maximum 8-h ozone averages reached 65-70 ppbv across the state of Maryland on 13 April as southwest winds transported the smoky air mass into the region. However, this modified air mass was transported out of the CONUS by 15 April and 8-h ozone dropped to natural background concentrations (near or below 45 ppbv) for all areas of the eastern CONUS as a midlatitude cyclone exerted its influence.

ENVIRONMENTAL SETUP. A seasonally strong jet stream in excess of $100 \mathrm{kt}\left(1 \mathrm{kt} \approx 0.5144 \mathrm{~m} \mathrm{~s}^{-1}\right.$; Fig. 2a) supported deepening of an upper-level trough as it crossed the Rocky Mountain West into a closed cyclone through $500 \mathrm{hPa}$ across the Great Plains by 14 April 2018 (Fig. 2b). In the process of deepening, strong differential advection and upper-level forcing resulted in a $985-\mathrm{hPa}$ surface low (Fig. 2c), bulk 0-6-km wind shear in excess of $100 \mathrm{kt}$, and warm sector surface dewpoints in the low to mid-60s $\left({ }^{\circ} \mathrm{F}\right)$ ahead of a cold front extending southward from the surface low into the Gulf of Mexico. The environmental setup resulted in storms responsible for over 80 tornadoes and other severe weather to parts of the lower Mississippi Valley and southeast CONUS 13-15 April 2018 (Storm Prediction Center 2018) with a severe linear complex across the southeast CONUS by 0000 UTC 16 April 2018. Continued deepening of the system, particularly at low levels of the troposphere, produced a closed system encompassing the entire eastern half of the CONUS by 15-16 April (Fig. 2).

The expansive upper-level closed low further deepened from 0000 to 1200 UTC 16 April, resulting in 60 - and $30-\mathrm{m}$ height falls at 925 and $850 \mathrm{hPa}$, respectively. These height falls were focused within a southeastward developing short-wave trough axis from the central low over the Great Lakes extending toward the Carolinas on the 1200 UTC analysis (dashed line, Fig. 3a). A combination of deepening and eastward progression of this secondary trough axis resulted in 120 -m height falls in $12 \mathrm{~h}$ at $850 \mathrm{hPa}$ over the central mid-Atlantic. Maryland surface monitors recorded surface pressure falls greater than $12 \mathrm{hPa}$ over the $12 \mathrm{~h}$ prior to the arrival of the gust front as a secondary surface cyclone moved into the region in concert with the falling heights aloft. This secondary cyclone deepened $3 \mathrm{hPa}$ between 0300 and 1200 UTC 16 April 2018 as it developed in the lee of the Appalachian Mountains and tracked northeastward along the warm front into Maryland.

The 1200 UTC 16 April radiosonde from the National Weather Service Office in Sterling, Virginia (LWX; $38.976^{\circ} \mathrm{N}, 77.485^{\circ} \mathrm{W} ; 150 \mathrm{~km}$ WSW of Millington), a western suburb of Washington, D.C., recorded a deep dry layer above $4 \mathrm{~km}$ MSL $(\sim 600 \mathrm{hPa})$. This dry layer had similar dewpoint depressions through altitudes considered stratospheric (e.g., pressure $<200 \mathrm{hPa}$; Fig. 3b). Relative humidity from approximately $4 \mathrm{~km}$ through the remainder of the profile was less than $20 \%$. Relative humidity less than $20 \%$ is an established condition for SI in the upper atmosphere (i.e., Sullivan et al. 2015). Winds through this deep dry layer were southerly, sometimes in excess of $100 \mathrm{kt}$. These strong winds were noticeable along the southeastern portion of the midlatitude cyclone 



Fig. 2. Atmospheric analyses at 1200 UTC 14-16 Apr 2018 for (a) 300 hPa. Blue-shaded contours show wind speeds in excess of $75 \mathrm{kt}$, with additional intervals of $25 \mathrm{kt}$. Yellow contours show divergence. Gray lines are streamlines. (b) 500-hPa geopotential heights (black lines), temperature (dashed red), and upper-level observations of winds (blue barbs, kt), temperature (red), dewpoint depression (green), and height (purple, dam) [source: Storm Prediction Center (SPC)]. (c) Weather Prediction Center (WPC) surface analysis.

(Fig. 3a) just east of the annotated trough axis along the mid-Atlantic coastline.

At the surface, a warm front retreated northward across Maryland, arcing from Washington, D.C., toward Millington, Maryland, at 0900 UTC, moving to the northern Chesapeake Bay coastline by 1200 UTC (Fig. 3c). The front then lifted through the northeastern corner of Maryland into southeastern Pennsylvania and northern Delaware by 1500 UTC. Meanwhile, a trailing cold front was draped southward across North Carolina at 0900 UTC, and arrived over southern Maryland by 1200 UTC (Fig. 3c). The $850-\mathrm{hPa}$ trough axis was generally parallel with but preceded (east) the cold front at 1200 UTC (cf. Figs. 3a and $3 \mathrm{c}$ ). This put areas impacted by enhanced ozone within the warm sector. The surface low and associated cold front swept through Maryland by 1700 UTC 16 April. The scenario allowed enhanced ozone to persist for a 7-h period in parts of Maryland.

\section{EVENT OBSERVATIONS. Radar and the MDE} network. An ongoing mesoscale convective band across the Gulf Coast states during the morning of 15 April reorganized with diurnal heating in a high-shear environment and produced an abundant number of high wind and tornado reports from South Carolina through south-central Virginia into late evening 15 April and early morning 16 April. The convection underwent reorganization and consolidation around 0500-0600 UTC 16 April, and broken linear storm bands morphed into a solid squall line initially with an expansive trailing stratiform (TS) rain region (Figs. 4-6). Over the next several hours, precipitation increased ahead of the main line, though a distinct linear band of $50+\mathrm{dBZ}$ was maintained as storms moved through Maryland. Radar radial velocities and MDE surface meteorology monitors captured a well-defined gust front coincident with the $50+\mathrm{dBZ}$ convective band. Individual storm tracks 
were generally north-northeast with some quickening of the eastward progression of the line evident after 0600 UTC.

The passage of the squall-line gust front corresponded precisely with a sudden ozone increase. A band of radar reflectivity greater than $50 \mathrm{dBZ}$ was directly over the Southern Maryland (S. Maryland) monitor $\left(38.504^{\circ} \mathrm{N}, 76.812^{\circ} \mathrm{W}\right)$ of the MDE ozone network on the 0654 UTC scan from the LWX radar (Fig. 4a). A distinct gust front was coincident with the band based on the discontinuity shown with LWX radial velocities (Fig. 4b). S. Maryland's ozone

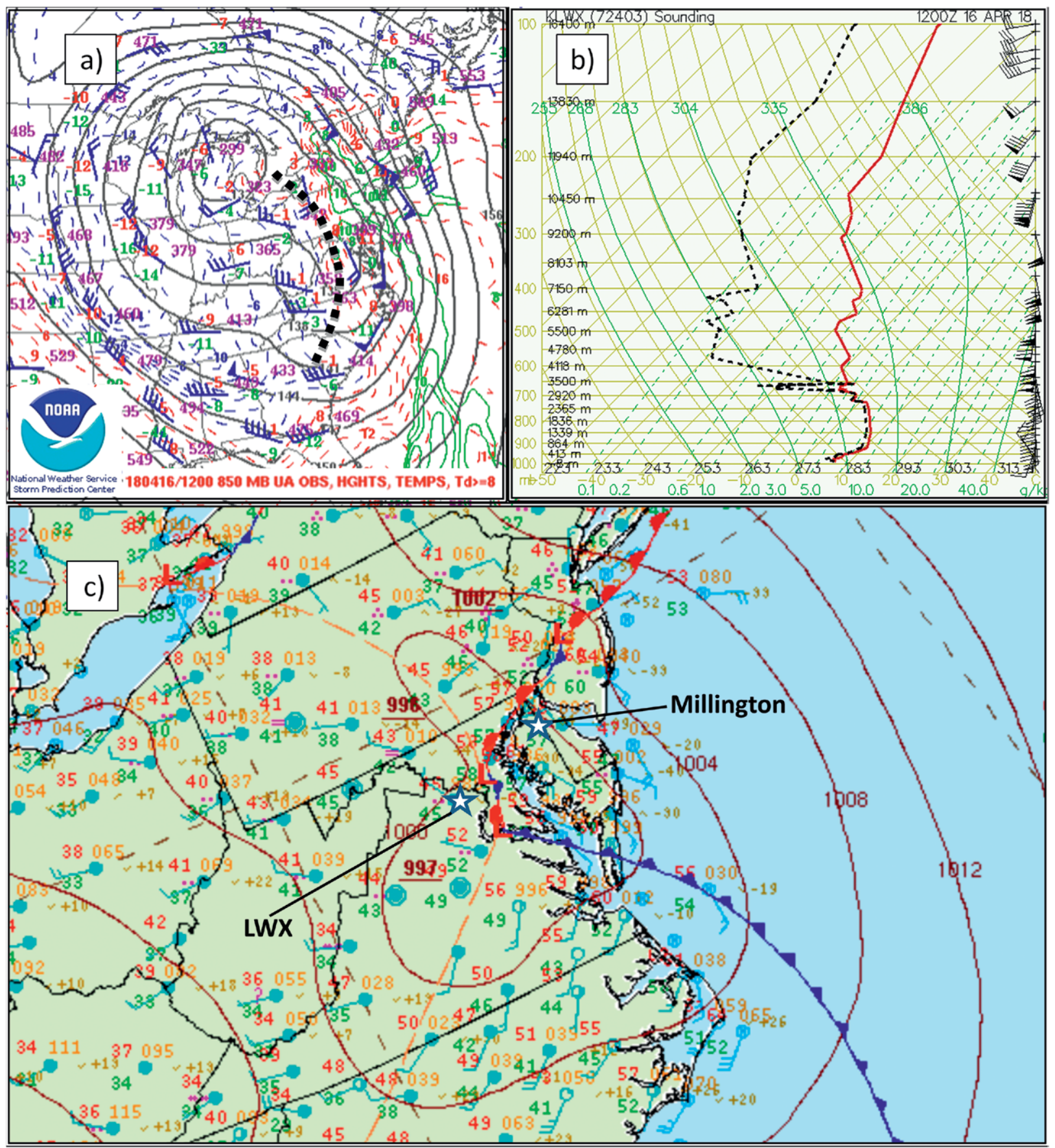

Fig. 3. (a) Geopotential height, temperature, winds, and dewpoint $>0^{\circ} \mathrm{C}$ at $850 \mathrm{hPa}$ at $1200 \mathrm{UTC} 16 \mathrm{Apr} 2018$. The black dashed line highlights a trough axis within the cyclonic flow of the larger cyclone (source: SPC). (b) Rawinsonde from Sterling, VA (LWX; $38.976^{\circ} \mathrm{N}, 77.485^{\circ} \mathrm{W}$ ), from 1200 UTC 16 Apr 2018. Red line is temperature; black dashed line is dewpoint, both in ${ }^{\circ} \mathrm{C}$. Winds are kt. (Source: Plymouth State Weather.) (c) WPC surface analysis at I200 UTC I6 Apr 2018. LWX and Millington mentioned in the text are marked for reference. 
concentration jumped from 19 to nearly $60 \mathrm{ppbv}$ in the $20 \mathrm{~min}$ after the gust front passed (Fig. 4c). S. Maryland, the first monitor in the MDE network to be impacted, did not have collocated meteorological instrumentation. However, the nearby monitor at Prince George's County Equestrian Center (PG Eq Cntr, $38.812^{\circ} \mathrm{N}, 77.744^{\circ} \mathrm{W}$ ) provided meteorological surface conditions with collocated ozone instrumentation (Fig. 4c). Ozone increased at PG Eq Cntr following the wind direction change from southeast (approximately $140^{\circ}$ ) to southwest (maximum wind direction reached $247^{\circ}$ with a post-gust front average of approximately $200^{\circ}$ ) about 20 min after the ozone jump at S. Maryland. While the rate of ozone increase was not identical between the two sites, the magnitude was similar. Ozone concentrations remained elevated until the cold front passed, as marked by the wind shift at 1345 UTC.

Ozone increased with the thunderstorm gust front throughout the eastern half of the MDE ozone network. The Dover, Delaware, weather surveillance radar (DOX) showed the squall line and gust front arriving at Horn Point,




Fig. 4. (a) Radar reflectivity (dBZ) and (b) radial velocity (kt) from the Sterling, VA (LWX), weather surveillance radar lowest-elevation angle at 0654 UTC 16 Apr 2018 and (c) time series of minute-averaged surface meteorology and ozone. The strongest reflectivity returns in (a) were coincident with a gust front, annotated in (b) where air with a component of motion toward the radar (green, $<0 \mathrm{kt}$ ) met air with outbound component (red, $>0 \mathrm{kt}$ ) beneath the heaviest reflectivity. The ozone increases at the Maryland ozone monitors of S. Maryland (black, ppbv) and PG Eq Cntr (gray, ppbv) were coincident with the arrival of the gust front, identified with a wind direction shift $\left({ }^{\circ}\right.$, blue dots) at the same time as the gust front arrival on radar at PG Eq Cntr. Temperature (red, $\left.{ }^{\circ} \mathrm{F}\right)$, relative humidity (dashed green, \%), and dewpoint (solid green, ${ }^{\circ} \mathrm{F}$ ) at PG Eq Cntr are also given. Relative humidity displayed has been offset $20 \%$ lower for easier comparison and display purposes (e.g., $80 \%$ represents $100 \%$ ). 



Maryland $\left(38.587^{\circ} \mathrm{N}\right.$, $76.141^{\circ} \mathrm{W}$ ), at approximately 0820 UTC (Figs. 5a,b). A large amount of reflectivity had developed ahead of the main squall line by this time. However, the character of the gust front remained well defined (Fig. 5b). Upon the arrival of the gust front at Horn Point, Maryland, the ozone rate of increase was even faster and of greater magnitude (Fig. 5c) than at S. Maryland and PG Eq Cntr. From 0817 to 0828 UTC, ozone climbed $42 \mathrm{ppbv}$ at Horn Point as the wind shifted from southeast $\left(133^{\circ} 5\right.$-min average before the wind shift) to southwest $\left(233^{\circ} 5\right.$-min average at 0820 UTC) before returning to $115^{\circ}-130^{\circ}$ by 0900 UTC.

The highest increase in ozone came at Millington, Maryland $\left(39.305^{\circ} \mathrm{N}\right.$, $\left.75.797^{\circ} \mathrm{W}\right)$. Despite radar reflectivity increasing ahead of the main line, the reflectivity gradient associated with the $50+\mathrm{dBZ}$ convective line became tighter by 0901 UTC (Fig. 6a), with what appears to be a line echo wave pattern (LEWP) north of the Millington site. A sharp convective gust front remained on radial velocity (Fig. 6b), with a change in wind direction from approximately

FIG. 5. (a) Radar reflectivity (dBZ) and (b) radial velocity (kt) from the Dover, DE (DOX), weather surveillance radar lowest-elevation angle at 0820 UTC 16 Apr 2018 and (c) time series of minute-averaged surface meteorology and ozone from Horn Point. The gust front, annotated in (b), was identified as the change between air with inbound component to the radar (green, $<0 \mathrm{kt}$ ) to air with outbound component (red, $>0 \mathrm{kt}$ ) seen between Essex and Horn Point. The ozone increase at Horn Point (black, ppbv) was coincident with the arrival of the gust front, identified with a wind direction shift $\left({ }^{\circ}\right.$, blue dots) at the same time as the gust front arrival on radar over Horn Point. Temperature (red, ${ }^{\circ} \mathrm{F}$ ), relative humidity (dashed green, $\%$ ), and dewpoint (solid green, ${ }^{\circ} \mathrm{F}$ ) at Horn Point are also provided. Relative humidity displayed has been offset $\mathbf{2 0} \%$ lower for easier comparison and display purposes (e.g., $80 \%$ represents $100 \%$ ). 
$120^{\circ}$ to nearly west (briefly at $256^{\circ}$ ) at Millington after gust front passage (Fig. 6c). Radar velocities showed passage of the gust front around 0901 UTC. Surface ozone readings at Millington jumped as the wind shifted from $120^{\circ}$ to $180^{\circ}$ from 22 to $70 \mathrm{ppbv}$ from 0903 to 0908 UTC, ultimately reaching a maximum 1-min value of 77 ppbv at 0924 UTC.

The northward extent of enhanced surface ozone was tied to the northward progression of the warm front. The gust front did not directly bring ozone to Maryland monitors located north of the surface warm front as the thunderstorms passed. Instead ozone concentrations at monitors fitting this scenario [e.g., Howard University Beltsville (HU-Beltsville) and Essex, Maryland] increased when winds switched to the southeast as the warm front lifted northward (Figs. 3c, 7). The strong northwestsoutheast gradient in ozone concentrations shown in Fig. 1a was the result of the northward progression of the warm sector after ozone had been deposited at the surface behind the thunderstorm gust front.

\section{Surface observations and} gaseous tracers. Stratospheric air is generally devoid of most anthropogenic pollutants found in the troposphere, such as carbon monoxide (CO). $\mathrm{CO}$ concentrations in the troposphere generally range from 40 to $200 \mathrm{ppbv}$, with lower concentrations in the stratosphere (Seinfeld and Pandis 1998). Surface meteorology
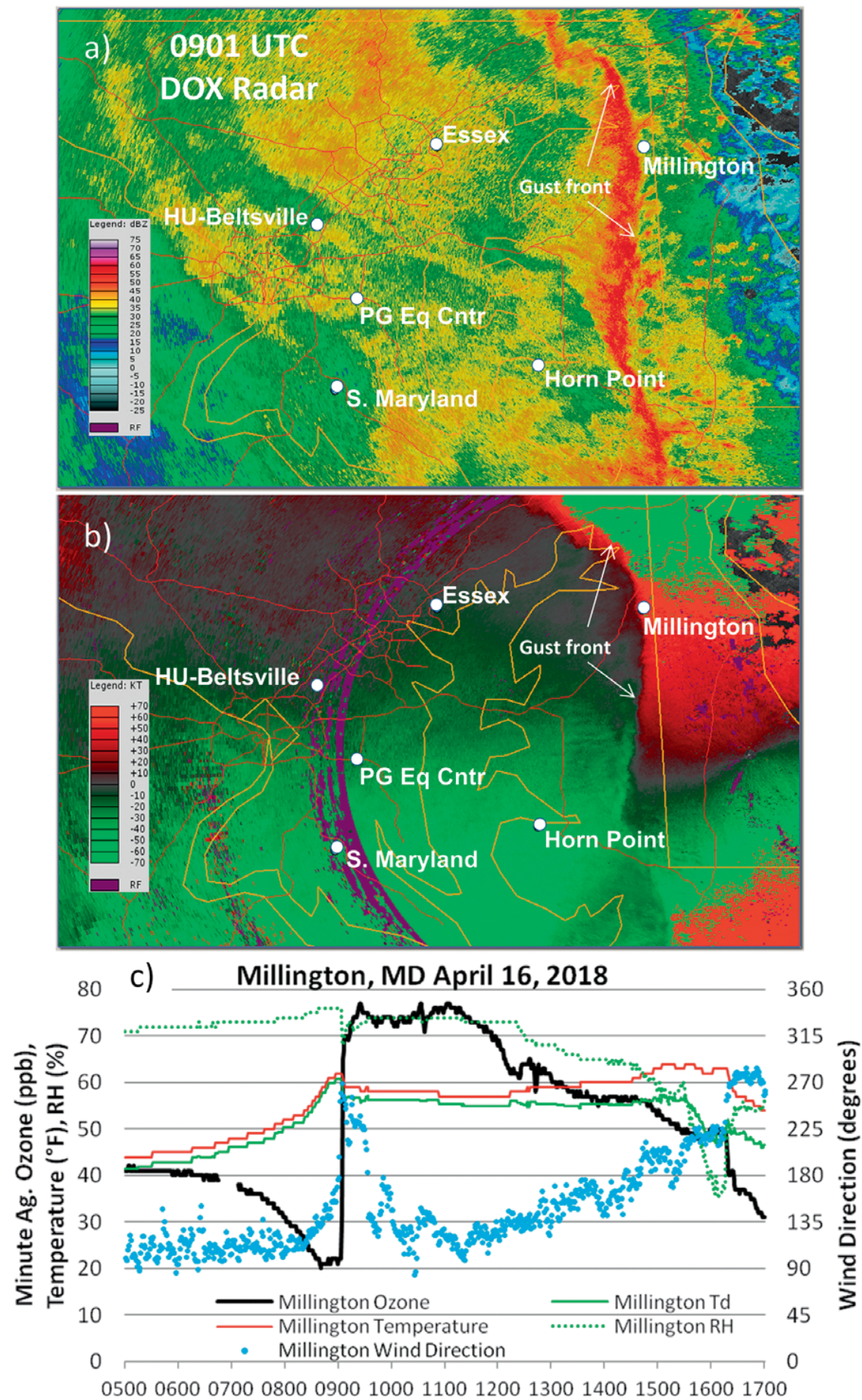

UTC

FIG. 6. (a) Radar reflectivity and (b) radial velocity as in Fig. 5, but for 090 I UTC and surface observations (c) at Millington, MD. Here the gust front was identified by the change in inbound velocities to the radar (green, $<0 \mathrm{kt}$ ) to air with outbound component (red, >0 kt) extending north and south from Millington.

and chemical observations at HU-Beltsville and Essex showed a relatively clean atmosphere based on $\mathrm{CO}$ measurements, with concentrations averaging 
approximately $70 \mathrm{ppbv}$ between 0500 and 0900 UTC 16 April 2018 prior to the gust front/warm front (Fig. 7). During the time of the ozone increase (1000-1300 UTC) at HU-Beltsville and Essex, both sites recorded a drop in $\mathrm{CO}$ concentrations to as low as $30 \mathrm{ppbv}$ at HU-Beltsville and $17 \mathrm{ppbv}$ at Essex, with an average of $51 \mathrm{ppbv}$ within the warm sector. This was followed by a rebound in CO concentrations behind the cold front to an average of $120 \mathrm{ppbv}$.

An initial decrease in relative humidity and dewpoint was observed as the gust front passed. At PG Eq Cntr, Horn Point, and Millington, relative humidity dropped immediately behind the gust front for roughly $5 \mathrm{~min}$ in concert with the ozone increase before increasing again as temperatures fell (Figs. $4 \mathrm{c}$, $5 c, 6 c)$. Since temperature acts inversely with relative humidity, the briefly correlated parameters implied drier air behind the gust front, corroborated by falling dewpoints as the gust front passed. Notable in these moisture variables was the increasing magnitude of the dewpoint and relative humidity decrease at the onset of the gust front with time and location through the MDE network. For example, PG Eq
Cntr experienced a $3^{\circ} \mathrm{F}$ dip and Horn Point a $6^{\circ} \mathrm{F}$ decrease in dewpoint temperature in 35 and $9 \mathrm{~min}$, respectfully, while a $5^{\circ} \mathrm{F}$ dewpoint decrease in just 3 min occurred at Millington. These quick changes in water vapor content were collocated with the greatest ozone increases, along a line from the S. Maryland to Millington monitor.

\section{UPPER-LEVEL PARAMETERS. MERRA-2} model output and satellite. The NASA Modern-Era Retrospective Analysis for Research and Applications version 2 (MERRA-2; Gelaro et al. 2017) is a reanalysis tool which assimilates observations into the Goddard Earth Observing System (GEOS; Molod et al. 2015) model which tracks the chemical state of the atmosphere. The model utilizes a finite-volume dynamical core based on a cubed-sphere horizontal discretization with approximate resolution of $0.5^{\circ} \times 0.625^{\circ}$, and 72 hybrid-eta levels from the surface to $0.01 \mathrm{hPa}$ (Putman and Lin 2007). Visualization of MERRA-2 data was made possible using the NASA Giovanni tool (Acker and Leptoukh 2007). Threehour time steps of GEOS reanalysis from MERRA-2



FIG. 7. In situ surface observations from Essex and HU-Beltsville from the MDE air monitoring network. CO is shown in blue (line), surface temperature $\left({ }^{\circ} \mathrm{F}\right)$ in red, dewpoint $\left({ }^{\circ} \mathrm{F}\right)$ in green, ozone (ppbv) in gray, and wind direction as dots. HU-Beltsville is distinguished from Essex using a lighter shading for each parameter. Note the missing ozone observations from Essex for 0945-1013 UTC were due to a weekly automated morning zero/ span check on the instrument. Both sites recorded drops in $\mathrm{CO}$ as the ozone concentrations increased as a warm front lifted northward, after the initial gust front had moved through. 
of three-dimensional ozone concentration, relative humidity, and Ertel's potential vorticity on 16 April 2018 showed a filament of 66-78 ppbv of ozone coincident with low relative humidity and higher potential vorticity extending from off the coast of the Carolinas northward into Maryland as of $1200 \mathrm{UTC}$ at $600 \mathrm{hPa}$ (Figs. 8a-c). The $600-\mathrm{hPa}$ level was the base of air with relative humidity $<20 \%$ that extended through the depth of the profile on the 1200 UTC LWX sounding (Fig. 3b). Infrared retrievals of midlevel tropospheric water vapor (WV) using band 9 of the Advanced Baseline Imager (ABI) on GOES-16 (Schmit et al. 2017) observed an intense dry slot west of the overnight thunderstorms (Fig. 8d). This observed dry slot corresponds well with the ribbon of ozone (Fig. 8a), low relative humidity (Fig. 8b), and heightened potential vorticity (Fig. 8c) at $600 \mathrm{hPa}$ analyzed in MERRA-2. Strong gradients in relative humidity collocated with enhanced ozone typify ozone intrusions, and potential vorticity of approximately 2 potential vorticity units (PVU; $1 \mathrm{PVU}=10^{-6} \mathrm{~K} \mathrm{~kg}^{-1}$ $\left.\mathrm{m}^{2} \mathrm{~s}^{-1}\right)$ is often considered the dynamic tropopause (Knowland et al. 2017). Areas of 1.5-2 PVU were present at $600 \mathrm{hPa}$ over Maryland (Fig. 8c), indicating the dynamic tropopause to be near $600 \mathrm{hPa}$. This was consistent with the LWX radiosonde (Fig. 3b) showing a layer of stratospheric-like dryness down to $650-600 \mathrm{hPa}(\sim 4 \mathrm{~km})$.

Vertical cross sections at $39^{\circ} \mathrm{N}$ (approximately midway between S. Maryland and Millington) from $95^{\circ}$ to $70^{\circ} \mathrm{W}$ analyzed ozone concentrations greater than 60 ppbv over an expansive region at and above $\sim 650 \mathrm{hPa}$ initially west of $82^{\circ} \mathrm{W}$ at $0300 \mathrm{UTC}$. The height was similar to the dry layer in the LWX sounding. A filament of ozone protruded farther downward at $82^{\circ} \mathrm{W}$ at 0300 UTC that progressed to

\section{MERRA-2 600mb Analyses/GOES-16 Water Vapor; 1200 UTC, April 16, 2018}
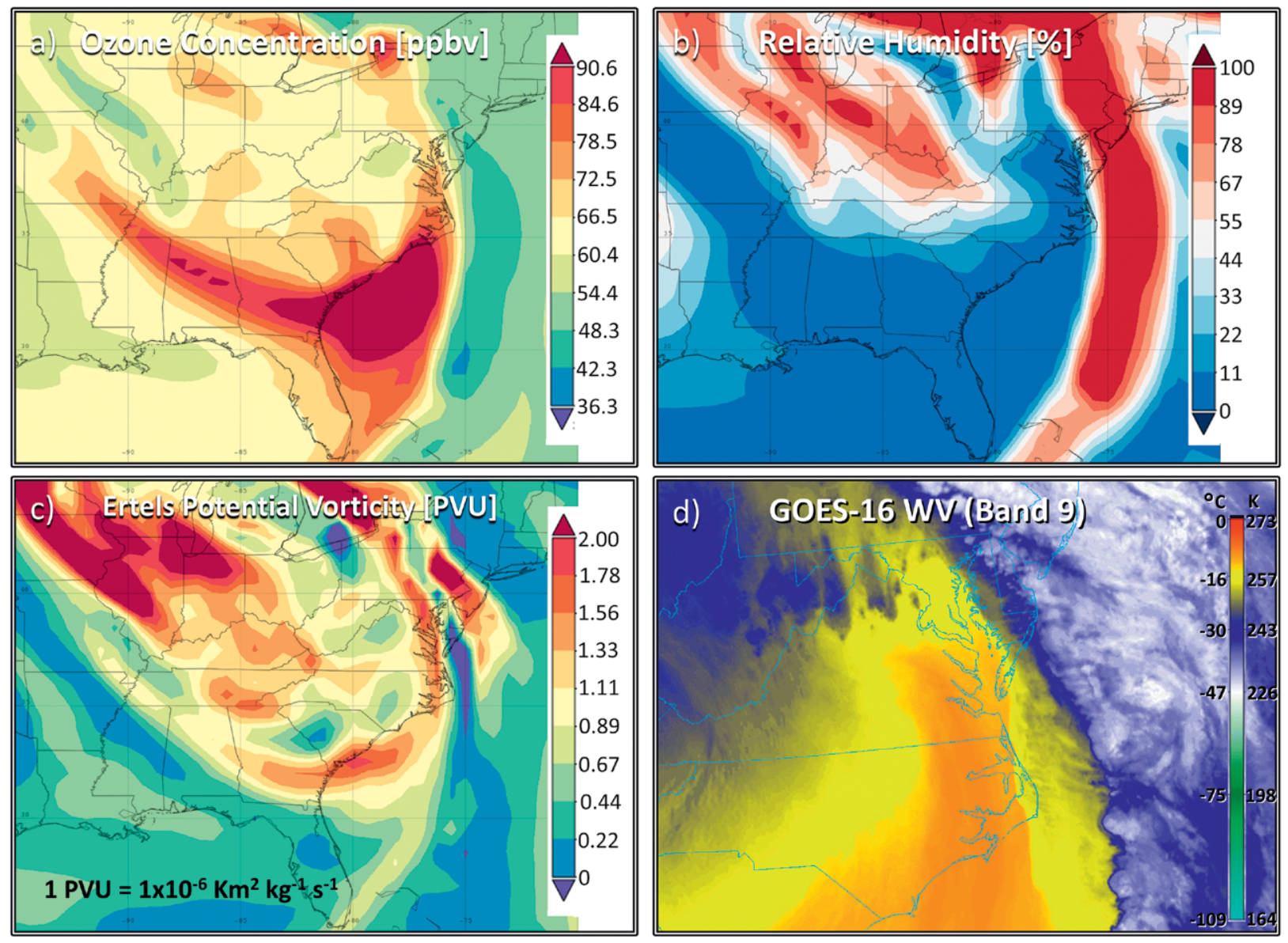

FIG. 8. Analyses from MERRA-2 at I200 UTC at the 600-hPa level for (a) ozone concentration (ppbv), (b) relative humidity (\% saturation), (c) Ertel's potential vorticity (in PVU), and (d) GOES-16 band 9 water vapor imagery from II47 UTC 16 Apr 2018 (source: College of Dupage). MERRA-2 plots are consistent with GOES-16 band 9 showing an intense dry slot moving in to southern Maryland on the back side of the squall-line cloud shield over the Atlantic. [Source: MERRA-2; data: GMAO (2015a,b).] 
$75^{\circ} \mathrm{W}$ by 1200 UTC 16 April 2018. MERRA-2 showed over 60 ppbv of ozone down to $925 \mathrm{hPa}$ (Fig. 9a). This filament (the SI) appeared to be strongest and broadest from 0600 to 0900 UTC, then showed some semblance of weakening on the 1200 UTC cross section as concentrations within the SI below $650 \mathrm{hPa}$ began to decrease. Throughout the $9 \mathrm{~h}$ presented and particularly at 0900 UTC, a stout horizontal gradient in ozone existed through the depth of the atmosphere starting from at least $950 \mathrm{hPa}(\sim 1,000 \mathrm{~m} \mathrm{ASL})$. No other vertical profile observations of ozone, such as ozonesondes, were requested by or known to the author during the event for comparison due to the anticipated unfavorable observational conditions.

Relative humidity cross sections showed moisture content within the tongue of ozone characteristic of the upper troposphere extending toward the surface from $80^{\circ}$ to $75^{\circ} \mathrm{W}$ during the hours of 0300 1200 UTC (Fig. 9b). This dry humidity profile was qualitatively similar to the observed LWX sounding (Fig. 3b), which extended into the stratosphere. This low relative humidity air descended over time within the SI, as shown by the downward progression of lower relative humidity within the area of $60+$ ppbv ozone (dark red in Fig. 9a) defining the SI. For example, at $0600 \mathrm{UTC}$, reanalyzed relative humidity at $775 \mathrm{hPa}$ was $55 \%-66 \%$, decreasing to $33 \%-44 \%$ at the front edge of the SI (0900 UTC), and below 33\% at 1200 UTC.

Some noted differences were apparent between MERRA-2 and observations. First, MERRA-2 nearsurface ozone concentrations were slightly high. The lowest concentrations in MERRA-2 were only as low as 40 ppbv (i.e., near the blue stars 0300-0900 UTC, Fig. 9a). No locations in the eastern CONUS outside of the locations presented in Fig. 1 had ozone greater than 40 ppbv overnight. Thus, MERRA-2 may have had a high bias at low levels or does not adequately represent the surface layer in this case since the model does not have tropospheric ozone chemistry in it. In contrast, while slightly high elsewhere, MERRA-2 surface ozone concentrations beneath the SI never get above 60 ppbv. Additionally, ozone within the SI above 60 ppbv remains west of the Chesapeake Bay in Maryland despite observed concentrations over 70 ppb east of the Bay by 0900 UTC (Fig. 9c). Despite these limitations, the reanalysis accurately captured prominent features, such as the dry slot observed via GOES-16 (cf. Figs. $8 \mathrm{~b}$ and $8 \mathrm{~d}$ ), during the event.

MDE radar wind profilers. Radar wind profilers (RWPs) of the MDE network monitored lower-troposphere wind evolution during the event. The MDE RWPs generate an average vertical wind profile up to $4 \mathrm{~km}$ above ground level (AGL) with every 6 min of continuous observation. A moving, backward averaging technique, with a 30 -min window of the vertical wind profiles was used for the final RWP output. The Horn Point RWP observed $80+\mathrm{kt}$ winds as low as $700 \mathrm{~m}$ AGL beginning approximately $1 \mathrm{~h}$ before the arrival of the gust front passage (Fig. 10). Intense accelerations in the wind field occurred leading to this time due to intensifying height falls. For example, winds at $1 \mathrm{~km}$ AGL accelerated from $\sim 57 \mathrm{kt}$ to over $80 \mathrm{kt}$ from 0500 to 0830 UTC. The Horn Point RWP also observed an intense vertical gradient in velocity around $400 \mathrm{~m}$ AGL from 0600 to 0830 UTC. The increased southwest winds transformed the south-southwestnorth-northeast-oriented mesoscale convective system into one with characteristics more consistent with parallel stratiform (PS) or leading stratiform (LS) precipitation archetype from the preexisting trailing stratiform (TS) archetype, as evidenced by increased reflectivity ahead of the squall line, due to intensification of squall-line-parallel storm-relative winds (Parker and Johnson 2000). After the gust front passage (0820 UTC) wind speeds toward the surface increased with $30-\mathrm{kt}$ winds observed within $100 \mathrm{~m}$ of the ground. Wind speeds quickly decelerated after passage of the gust front to mainly lower than $60 \mathrm{kt}$ through 3,000 m even as ozone at the site remained elevated.

\section{DISCUSSION: COUPLING SI AND CON-} VECTION. This rare event was possible due to a vigorous upper-level trough, resulting SI, and associated descending lobe of enhanced ozone interacting with a squall line within the warm sector of a developing surface cyclone. The juxtaposition of these elements allowed transport of the SI directly to the surface augmented by storm-scale dynamics of the squall line. At the largest scale, an advancing amplified trough at $300 \mathrm{hPa}$, created height falls over the eastern CONUS within an already deeply closed system through $500 \mathrm{hPa}$ with enhanced ozone concentrations greater than $90 \mathrm{ppbv}$ noted at $600 \mathrm{hPa}$ over the southeast CONUS. It was likely topographic stretching of the column in the lee of the Appalachian Mountains aided surface cyclone development in concert with height falls over Virginia. Simultaneously, the vertical wind field accelerated and mass adjustments in response induced downward motion on the cyclonic (west/north) side of the jet, similar to that discussed in Danielsen (1968). Strengthening winds then transported this subsiding filament of ozone northward from a pool of ozone located over the 
a) Cross-Section Ozone Concentration, $39^{\circ} \mathrm{N}$
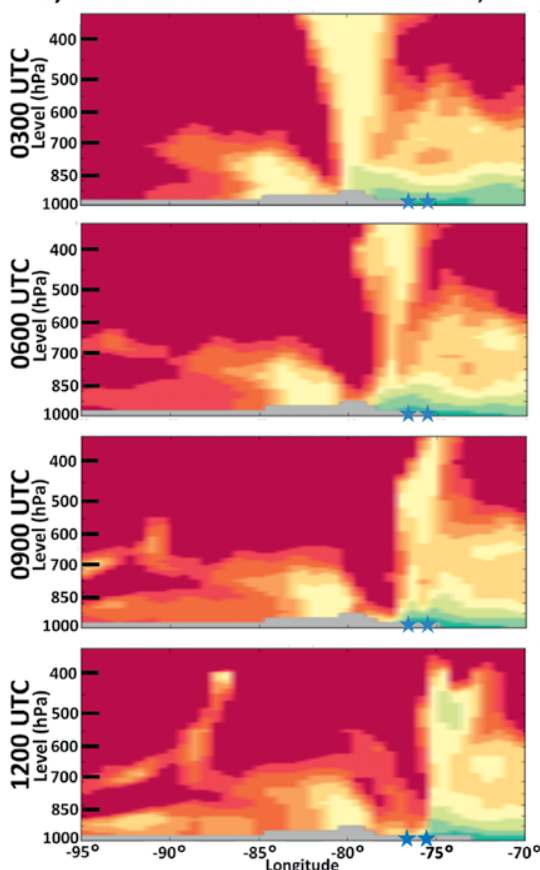

b) Cross-Section Relative Humidity, $39^{\circ} \mathrm{N}$
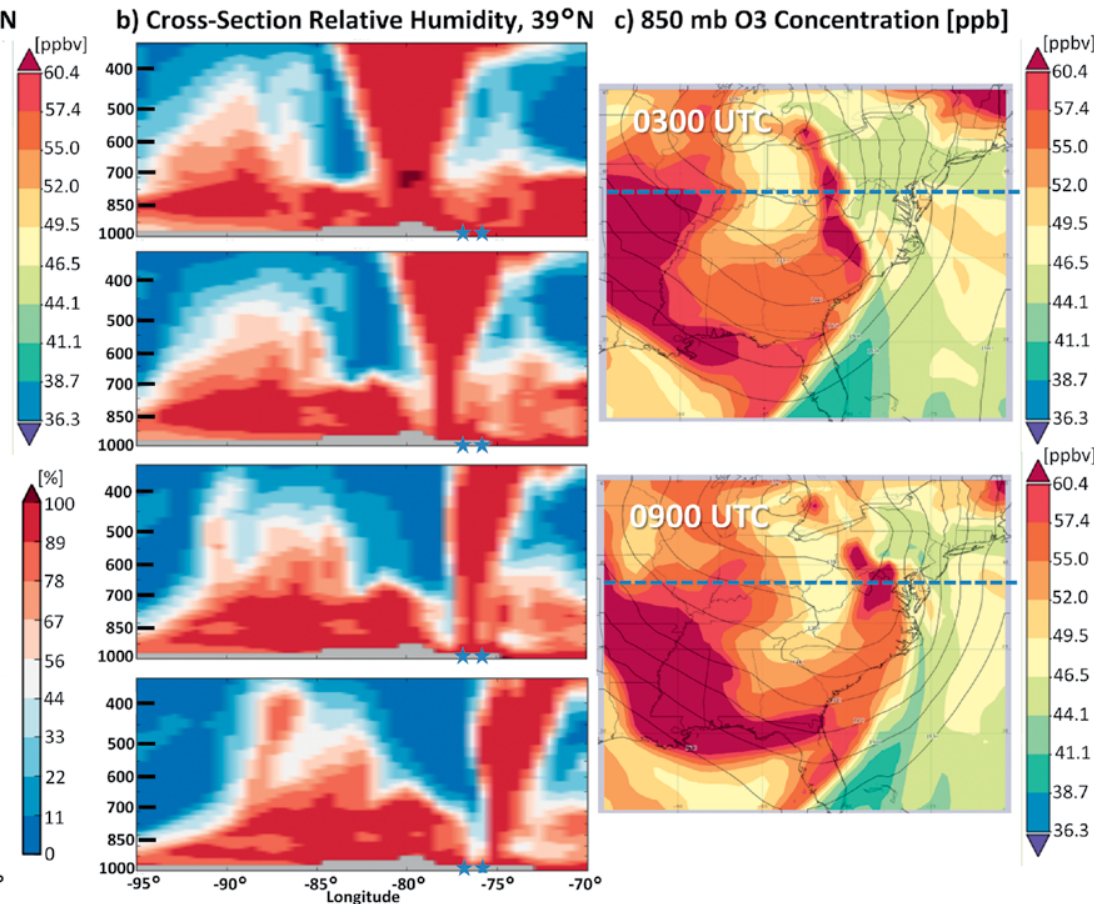

FIG. 9. Cross sections during 0300-1200 UTC across the $39^{\circ} \mathrm{N}$ latitude vertical slice from $95^{\circ}$ to $70^{\circ} \mathrm{W}$ of (a) ozone mixing ratio and (b) relative humidity. The cross sections show the downward and eastward progression of the SI. For the ozone cross section, the darkest reds show concentrations greater than 60 ppbv. The relative humidity vertical profile has dark blues to represent the driest air while dark red is saturated air. Dry air (dark blue) was collocated with the SI (ozone greater than 60 ppbv extending below $850 \mathrm{hPa}$ east of $80^{\circ} \mathrm{W}$ ) and progressed toward lower elevation with time. The two dark blue stars show the longitude of the S. Maryland (left star) and Millington (right star) surface monitors in Maryland. (c) Horizontal analyses at $850 \mathrm{hPa}$ at 0300 and 0900 UTC show the ribbon of ozone at low levels. The dashed line indicates the location of the cross sections in (a) and (b) and thin black lines are geopotential heights. The darkest red indicates areas of ozone concentrations greater than 60 ppbv. [Source: MERRA-2; data: GMAO (20I5a,b).]

southeastern CONUS to over Maryland by 1200 UTC 16 April. This filament of ozone traveled toward the deepening surface low in the lee of the Appalachians of Virginia, and into the back side of the squall line impacting central Virginia at the time. Downward motions associated with the thunderstorms then brought the SI ozone the remaining distance to the ground within the gust front.

The drop in wind speed above the surface over Horn Point immediately after the passage of the gust front (0820 UTC) indicated the squall line was located on the western (cold) edge of the jet. This is where SIs are generally located, due to favorable subsidence on the cold/cyclonic side of the jet streak (Danielsen 1968), although generally these processes transpire in the upper troposphere. Locations west of the trough axis are the preferred location for SI development (Mohanakumar 2008). For example, in previous cases, SIs remained spatially behind the surface cold front at low altitudes (Knowland et al. 2017) and at the surface (Dempsey 2014). The setup on 16 April, however, observed the SI east of the trough axis (cf. Figs. 3a and 3c) as the jet streak and SI were over the warm sector. This enabled interaction with surface-based thunderstorms due to the convectively supportive vertical profile. The temporal coincidence of the ozone increase at Horn Point and diminishing upper-level winds as the gust front passed indicated the thunderstorms, edge of the jet, and the ozone within the SI were juxtaposed. This also implied the sudden decrease in the wind speed profile over Horn Point was within the SI (and enhanced ozone) itself and that the intense winds speeds to $700 \mathrm{~m}$ and tight velocity gradient at $400 \mathrm{~m}$ may indicate the height of the SI layer prior to entrainment in the thunderstorms. Thus, strong downward dynamic motion brought the SI ozone toward the surface along an accelerating low-level jet and into ongoing thunderstorms, which made entrainment of ozone into convective downdrafts possible, spatially phasing all elements of downward motion together.

This study cannot rule out that ozone may have reached the surface solely via the dynamical process involving the intense jet and developing cyclone 


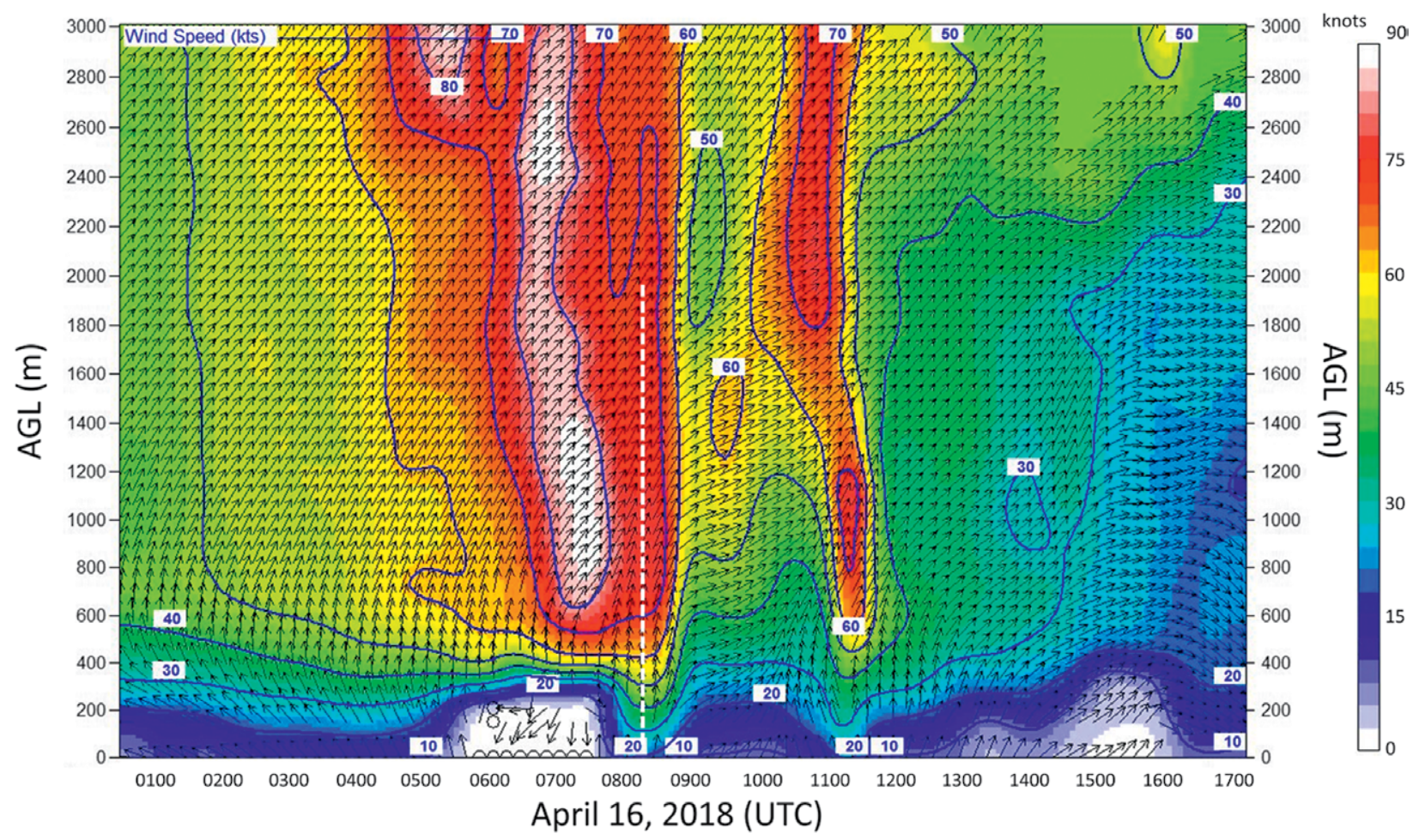

FIG. 10. The radar wind profiler at Horn Point, MD, measured wind speed (kt, filled colors and isotachs), direction ( ${ }^{\circ}$, arrows), against height above ground level (AGL, $m$ ), and time (UTC). Direction arrows give the $u-U$ (east west, north/south) direction of the wind. An arrow pointing straight up indicates a southerly wind at that height/ time. Maximum wind speeds reached $88 \mathrm{kt}$ between 0700 and 0800 UTC around I km AGL. The white dashed line shows the time the gust front passed over the site (0820 UTC). Horn Point has an elevation of $4 \mathrm{~m} \mathrm{MSL.}$

described above. However, additional evidence indicated downward motion within the thunderstorms enhanced, if not entirely enabled, the surface ozone increase by entraining greater ozone from further aloft in the SI. No low-altitude monitors (i.e., excluding the mountaintop SNP monitor) observed a nocturnal ozone increase outside of the warm sector and squall line. The Prince Edward County monitor saw mild increases within strong trailing stratiform rain. The high-elevation monitor at SNP was well behind the front edge of the squall line at 0600 UTC when it recorded a stronger increase in ozone concentration, indicating the ribbon of ozone was delivered to the rear of the squall line and downward to at least 1,070 m. However, no other surrounding non-mountain monitors recorded such increases, indicating the ozone remained elevated in altitude. Yet at the same time, ozone in Richmond rose at an even greater rate as the gust front moved through, suggesting the squall line was effective in transporting ozone farther east and downward, as evidenced through the state of Maryland. This increasing entrainment of the SI in the squall line explains the large range in ozone changes noted during the event. For example, the maximum 1-h change in ozone concentration has a factor of 5 range in Table 1. This heterogeneity was likely due to both proximity to and strength of convective elements (i.e., updrafts/downdrafts) and the timing and location relative to ozone aloft (the SI). Ozone brought to the surface within the stratiform precipitation was mixed downward broadly and relatively slowly. In contrast, as the SI ribbon was juxtaposed with the front of the linear complex of storms (i.e., the squall line), the downward motions were larger, resulting in larger 1 -h increases. The SI may have still been dynamically descending in height as well. Separating dynamic motions from those within the squall line is not possible given the resolution of MERRA-2.

MERRA-2 was slower, west, and aloft compared to the observed event. The analyzed ribbon of ozone within the vertical cross section (Fig. 9a) was some distance behind the thunderstorm gust front through 1200 UTC. For example, S. Maryland and Millington on the cross section (blue stars in Fig. 9) remained several degrees east of the SI. By 0900 UTC, surface ozone had already increased at Millington, yet MERRA-2 showed the SI moving over the location at 1200 UTC (Figs. 8a, 9a). The MERRA-2 cross section also showed the greatest ozone at the longitude of 
S. Maryland at 0900 UTC (left star, Fig. 9a) which, like Millington, had already had an ozone jump several hours earlier (0654 UTC). A spatial discrepancy between the ribbon of ozone aloft and surface ozone was evident even as early as 0600 UTC with the MERRA-2 ozone cross sections, showing ozone only as far east as $78.5^{\circ} \mathrm{W}$ at $\sim 800 \mathrm{hPa}, 1^{\circ}$ longitude west of Richmond (Fig. 9a). Recall the increase there occurred by 0600 UTC. The GOES-16 ABI band 9 (Fig. 8d) WV imagery of the dry slot substantiates the timing of large-scale features in MERRA-2. For instance, the eastern edge of the dry slot was just reaching Millington at 1200 UTC as viewed by GOES-16. However, cross sections of Fig. 9 indicated ozone concentrations of $60 \mathrm{ppbv}$ and greater stayed above the bottom model layer. Discrepancies in ozone location could be due to the capability of the model to resolve the finescale features. At least some portion of the convection would be subgrid scale and perhaps not adequately represented by the convective parameterization of the MERRA-2 GEOS model. Since the model parameterizations do not account for storm interactions on a subgrid scale, it likely explained why MERRA-2 developed the lobe of ozone at low levels west of that observed, further implicating the convective role in this case.

A thunderstorm rear inflow may explain the discrepancy observed between the model and observations. The following mechanism is proposed. Mature convective systems develop rear-to-front storm relative winds from midlevels of the troposphere. This rear inflow descends in altitude as it approaches the front of the storm, bringing midtropospheric air toward the surface. In the 16 April event, as ozone-laden air approached the rear of the squall line, storm-relative rear inflow enhanced the downward and eastward progression of the ozone. Simultaneously, strong accelerations in the vertical wind field may well have acted as, or at least augmented the rear inflow to the system. Strong rear inflow to convective systems can merge with convective downdrafts to enhance the surface gust front (Smull and Houze 1987). Rear inflow sourced from a low-elevation SI could enhance the gust-front ozone gradient as observed in this case. Weaker downdrafts associated with stratiform precipitation could entrain some ozone to the surface, accounting for more subtle increases as that seen at Prince Edward County. While previous cases have observed ozone from SI reaching the surface, the intense vertical motions provided by the collocation of convection and descending ribbon of ozone brought more stratospheric ozone to a lower elevation in a quicker time than ever before documented along the U.S. East Coast.

\section{EVENT SIGNIFICANCE AND FUTURE}

WORK. While SI events have been well documented (e.g., Sullivan et al. 2015; Ott et al. 2016; Knowland et al. 2017), there are no known cases impacting lowelevation/sea level monitors to such a magnitude in such a manner as that on 16 April 2018. SIs could occur frequently along the U.S. East Coast, but the unique circumstances leading to stratospheric ozone at sea level made this event exceptional. The SI, evidenced by high ozone, low $\mathrm{CO}$, and lower relative humidity behind the gust front, occurred within the warm sector of a midlatitude cyclone. Such an occurrence was atypical, as SI and enhanced ozone are more often associated with cold frontal passages and the descending conveyor belt of the midlatitude cyclone model. In this case, however, the cold front swept out the SI air at the surface. Interaction between the SI and thunderstorms in this case was also significant. If convection was a requirement for an SI to be transported directly to sea level altitudes, it may only be possible within the warm sector due to the need for convective instability.

Succinctly, there are several aspects that make this ozone event unique and significant:

1) this may be the first recorded SI bringing ozone directly to sea level;

2) coupling of an SI with a mesoscale convective squall line;

3) surface ozone increases at night;

4) surface ozone increases due to a thunderstorm; and

5) potential implications for federal air quality standard compliance, health, and the chemical budget of the atmosphere.

While this event did not violate National Ambient Air Quality Standards (NAAQS), the event showed that high concentrations of ozone within stratospheric air can be an issue at lower elevations. Indeed, a period of enhanced ozone existed for $7 \mathrm{~h}$. Given a lower ozone standard or stronger event, future events like 16 April 2018 could potentially cause violations of the NAAQS along the East Coast. Additionally, the event showed that thunderstorms thought to primarily remove pollutants from the air can exacerbate air quality. Ironically, a lengthy history of wind damage reports through the Carolinas and southern Virginia associated with the squall line ended as surface ozone increased within the gust front. It was believed the SI altered the vertical shear, which changed the updraft tilt and decreased severe wind report frequency (Przybylinski 1995) but also 
created potentially adverse surface air quality. This event raises questions concerning the roles convection plays in global atmospheric chemistry, which could have profound impacts on large-scale climate and small-scale convection modeling. The rarity of the occurrence described in this manuscript makes this a novel event, as there are no known documented cases of stratospheric ozone directly reaching sea level elevations within a thunderstorm.

Follow-up work will assess the event at finer resolutions and focus on the juxtaposition of convection and the SI. MERRA-2 was able to capture the largescale features driving the event, but higher resolution is needed to fully characterize the mechanism and coupling of vertical transport of ozone toward the surface and the predictability of such an occurrence in the future.

ACKNOWLEDGMENTS. The author gratefully acknowledges the Maryland Department of the Environment and Virginia Department of Environmental Quality as in situ high-resolution data sources. Analyses and visualizations used in this paper were produced with the Giovanni online data system, developed and maintained by the NASA GES DISC. Those making MERRA-2 data available and all associated NASA personnel are also acknowledged for the production of the data used in this research effort. The author also thanks those providing input and feedback on the analyses presented.

\section{REFERENCES}

Acker, J. G., and G. Leptoukh, 2007: Online analysis enhances use of NASA Earth science data. Eos, Trans. Amer. Geophys. Union, 88, 14-17, https://doi .org/10.1029/2007EO020003.

Appenzeller, C. H., H. C. Davies, and W. A. Norton, 1996: Fragmentation of stratospheric intrusions. J. Geophys. Res., 101, 1435-1456, https://doi .org/10.1029/95JD02674.

Danielsen, E. F., 1968: Stratospheric-tropospheric exchange based on radioactivity, ozone and potential vorticity. J. Atmos. Sci., 25, 502-518, https://doi .org/10.1175/1520-0469(1968)025<0502:STEBOR $>2.0 . \mathrm{CO} ; 2$.

Davies, T. D., and E. Schuepbach, 1994: Episodes of high ozone concentrations at the Earth's surface resulting from transport down from the upper troposphere/ lower stratosphere: A review and case studies. Atmos. Environ., 28, 53-68, https://doi.org/10.1016/1352 -2310(94)90022-1.

Dempsey, F., 2014: Observations of stratospheric $\mathrm{O}_{3}$ intrusions in air quality monitoring data in Ontario,
Canada. Atmos. Environ., 98, 111-122, https://doi .org/10.1016/j.atmosenv.2014.08.024.

Dreessen, J., J. Sullivan, and R. Delgado, 2016: Observations and impacts of transported Canadian wildfire smoke on ozone and aerosol air quality in the Maryland region on June 9-12, 2015. J. Air Waste Manag. Assoc., 66, 842-862, https://doi.org/10.1080/109622 47.2016.1161674.

EPA, 2015: 2015 National Ambient Air Quality Standards (NAAQS) for ozone. Environmental Protection Agency, accessed 17 October 2018, www.epa.gov /ozone-pollution/2015-national-ambient-air-quality -standards-naaqs-ozone.

Gelaro, R., and Coauthors, 2017: The Modern-Era Retrospective Analysis for Research and Applications, version 2 (MERRA-2). J. Climate, 30, 5419-5454, https://doi.org/10.1175/JCLI-D-16-0758.1.

GMAO, 2015a: MERRA-2 inst3_3d_chm_Nv: 3D, 3-hourly, instantaneous, model-level, assimilation, carbon monoxide and ozone mixing ratio v5.12.4. Goddard Earth Sciences Data and Information Services Center, accessed November 2018, https://doi .org/10.5067/HO9OVZWF3KW2.

—, 2015b: MERRA-2 inst3_3d_asm_Nv: 3D, 3-hourly, instantaneous, model-level, assimilation, assimilated meteorological fields v5.12.4. Goddard Earth Sciences Data and Information Services Center, accessed November 2018, https://doi.org/10.5067 /WWQSXQ8IVFW8.

Jerrett, M., and Coauthors, 2009: Long-term ozone exposure and mortality. N. Engl. J. Med., 360, 1085-1095, https://doi.org/10.1056/NEJMoa0803894.

Knowland, K. E., L. E. Ott, B. N. Duncan, and K. Wargan, 2017: Stratospheric intrusion-influenced ozone air quality exceedances investigated in the NASA MERRA-2 reanalysis. Geophys. Res. Lett., 44, 1069110 701, https://doi.org/10.1002/2017GL074532.

Kuang, S., M. J. Newchurch, J. Burris, L. Wang, K. Knupp, and G. Huang, 2012: Stratosphereto-troposphere transport revealed by groundbased lidar and ozonesonde at a midlatitude site. J. Geophys. Res., 117, D18305, https://doi.org /10.1029/2012JD017695.

Langford, A. O., and Coauthors, 2015: An overview of the 2013 Las Vegas Ozone Study (LVOS): Impact of stratospheric intrusions and long-range transport on surface air quality. Atmos. Environ., 109, 305-322, https://doi.org/10.1016/j.atmosenv.2014.08.040.

Lin, M., and Coauthors, 2012: Springtime high surface ozone events over the western United States: Quantifying the role of stratospheric intrusions. J. Geophys. Res., 117, D00V22, https://doi .org/10.1029/2012JD018151. 
Mohanakumar, K. 2008: Stratosphere Troposphere Interactions: An Introduction. Springer Science \& Business Media, 416 pp.

Molod, A., L. Takacs, M. Suarez, and J. Bacmeister, 2015: Development of the GEOS-5 atmospheric general circulation model: evolution from MERRA to MERRA2. Geosci. Model Dev., 8, 1339-1356, https:// doi.org/10.5194/gmd-8-1339-2015.

Ott, L. E., and Coauthors, 2016: Frequency and impact of summertime stratospheric intrusions over Maryland during DISCOVER-AQ (2011): New evidence from NASA's GEOS-5 simulations. J. Geophys. Res. Atmos., 121, 3687-3706, https://doi.org /10.1002/2015JD024052.

Parker, M. D., and R. H. Johnson, 2000: Organizational modes of midlatitude mesoscale convective systems. Mon. Wea. Rev., 128, 3413-3436, https:// doi.org/10.1175/1520-0493(2001)129<3413:OMOM $\mathrm{MC}>2.0 . \mathrm{CO} ; 2$.

Przybylinski, R. W., 1995: The bow echo: Observations, numerical simulations, and severe weather detection methods. Wea. Forecasting, 10, 203-218, https://doi .org/10.1175/1520-0434(1995)010<0203:TBEONS $>2.0 . \mathrm{CO} ; 2$.

Putman, W. M., and S. J. Lin, 2007: Finite-volume transport on various cubed-sphere grids. $J$.
Comput. Phys., 227, 55-78, https://doi.org/10.1016/j .jcp.2007.07.022.

Schmit, T. J., P. Griffith, M. M. Gunshor, J. M. Daniels, S. J. Goodman, and W. J. Lebair, 2017: A closer look at the ABI on the GOES-R series. Bull. Amer. Meteor. Soc., 98, 681-698, https://doi.org/10.1175/BAMS -D-15-00230.1.

Seinfeld, J. H., and S. N. Pandis, 1998: Atmospheric composition, global cycles, and lifetimes. Atmospheric Chemistry and Physics: From Air Pollution to Climate Change, John Wiley and Sons, 49-124.

Smull, B. F., and R. A. Houze Jr., 1987: Rear inflow in squall lines with trailing stratiform precipitation. Mon. Wea. Rev., 115, 2869-2889, https://doi. org/10.1175/1520-0493(1987)115<2869:RIISLW >2 .0.CO;2.

Storm Prediction Center, 2018: NWS local storm reports. NOAA/NWS, accessed 1 October 2018, www .spc.noaa.gov/climo/.

Sullivan, J. T., T. J. McGee, A. M. Thompson, R. B. Pierce, G. K. Sumnicht, L. W. Twigg, E. Eloranta, and R. M. Hoff, 2015: Characterizing the lifetime and occurrence of stratospheric-tropospheric exchange events in the Rocky Mountain region using high-resolution ozone measurements. J. Geophys. Res. Atmos., 120, 12410-12 424, https://doi.org/10.1002/2015JD023877. 


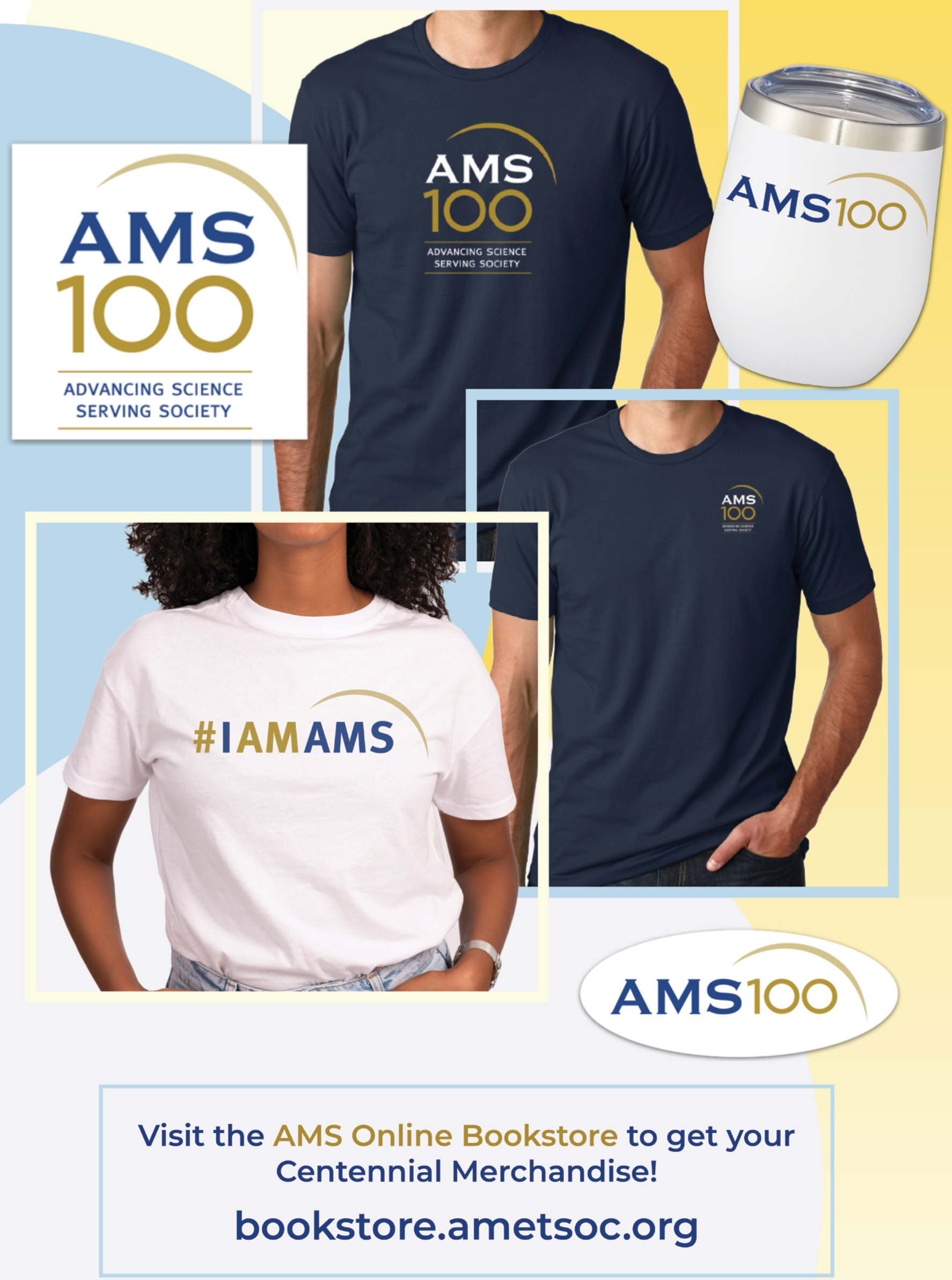

